\begin{tabular}{l|l}
\hline Votaice & $\begin{array}{l}\text { e-ISSN: } 2655-9404 \\
\text { DOI: } 10.20473 / \text { ntr.v2i2.13122 }\end{array}$ \\
\hline
\end{tabular}

Article history: Submitted 22 May 2019; Accepted 28 May 2019; Available online 1 June 2019.

\title{
Asas Itikad Baik dalam Memorandum of Understanding Sebagai Dasar Pembuatan Kontrak
}

\author{
Margaretha Donda Daniella, William Tandya Putra and Erich Widjaja Kurniawan \\ margarethadondaaa@gmail.com \\ Universitas Airlangga
}

\begin{abstract}
Memorandum of Understanding $(\mathrm{MoU})$ is one of the preliminary agreement forms used as a prelude to a more detailed and defined agreement. The existence of the MoU is based on the freedom of contract principle. MoU as a preliminary agreement, is in the pre-contract phase and has no binding force. Nevertheless, the parties are entitled to apply the principle of good faith in the making and implementing of $M o U$, because in the principle of good faith, $M o U$ is viewed as an important step to be carried out. This principle also makes the position of MoU is not weak because this obligation provides power for MoU to binds its parties to carry out obligations expressed in the MoU. The basic principles of the $\mathrm{MoU}$ are freedom of contract principle, consensualism principle, binding power of contract (pacta sent servanda), and the principle of good faith. MoU contains the parties'agreement on general matters instead of rights and obligations of the parties. If the MoU contains rights and obligations of the parties, the MoU has been losing its essence as an preliminary agreement and result in the binding power of contract. Thus, any breach of MoU can be sued as a breach of contract or unlawful act. However, as a preliminary agreement, a breach of contract can't be filed to MoU, as it does not contain the rights and obligations of the parties, and there is no promises were broken. Yet, a wrongful act lawsuit can be filed for any loss suffered by the injured party as a result of the breach of the $M o U$.
\end{abstract}

Keywords: Memorandum of Understanding; Preliminary Agreement; Good Faith.

\begin{abstract}
Abstrak
Memorandum of Understanding (MoU) merupakan salah satu bentuk dari perjanjian pendahuluan yang digunakan sebagai pendahuluan untuk mengadakan perjanjian selanjutnya yang lebih rinci dan pasti yang termasuk kedalam fase prakontrak. Pada prinsipnya MoU tidak memiliki kekuatan mengikat sebagaimana kontrak pada umumnya, sehingga para pihak diwajibkan untuk menerapkan prinsip itikad baik dalam pembuatan dan pelaksanaan MoU, karena prinsip itikad baik ini memandang bahwa MoU merupakan tahap penting untuk ditindaklanjuti. Prinsip-prinsip dasar dalam MoU ialah prinsip kebebasan berkontrak, prinsip konsensualisme, prinsip daya mengikat kontrak (pacta sunt servanda) dan prinsip itikad baik. Substansi dari MoU ialah berisi kesepakatan para pihak tentang hal-hal yang bersifat umum, dan bukannya berisi hak dan kewajiban para pihak. Jika substansi MoU memuat hak dan kewajiban para pihak, maka MoU tersebut telah kehilangan esensinya sebagai perjanjian pendahuluan dan mengakibatkan MoU tersebut mengikat para pihaknya dan memiliki kekuatan hukum, sehingga segala bentuk pelanggaran dari MoU dapat diajukan gugatan atas perbuatan wanprestasi ataupun perbuatan melanggar hukum. Akan tetapi terhadap MoU sebagai perjanjian pendahuluan tidak dapat diajukan gugatan wanprestasi karena dalam MoU tersebut tidak memuat hak dan kewajiban sehingga tidak ada janji yang diingkari, akan tetapi dapat diajukan gugatan perbuatan melanggar hukum atas kerugian yang diderita oleh pihak yang dirugikan akibat pengingkaran dari MoU tersebut.
\end{abstract}

Kata Kunci: Memorandum of Understanding; Perjanjian Pendahuluan; Itikad Baik. 


\section{Pendahuluan}

Dalam praktik bisnis, pembicaraan awal suatu kerjasama umumnya dituangkan dalam bentuk Memorandum of Understanding (untuk selanjutnya disebut MoU). Istilah MoU atau yang terkadang disebut dengan Nota Kesepahaman itu sendiri tidak dikenal dalam Burgerlijk Wetboek (untuk selanjutnya disebut BW), sehingga terdapat banyak macam pengertian dari MoU dan tidak ada pengertian pastinya.

Pada dasarnya istilah kontrak berasal dari bahasa Inggris yaitu “contract”. Dalam bahasa Perancis "contrat" dan dalam bahasa Belanda "overeenkomst" sekalipun kadang-kadang digunakan juga istilah "contract". Kedua istilah ini merupakan terjemahan dari "contrat", " overeenkomst”, dan “contract”. ${ }^{1}$ Dalam Black's Law Dictionary, kontrak diartikan dengan: "An agreement between two or more parties creating obligations that are enforceable or otherwise recognizable at law". ${ }^{2}$ Dalam bahasa Indonesia, pada intinya definisi dari contract dalam Black's Law Dictionary diatas ialah bahwa kontrak merupakan sebuah persetujuan diantara para pihak yang membuat kewajiban yang dapat dilaksanakan atau dikenali dalam hukum.

Agus Yudha Hernoko berpendapat, mengenai perumusan kontrak, bahwa pada dasarnya kontrak berawal dari perbedaan atau ketidaksamaan kepentingan di antara para pihak. Perumusan hubungan kontraktual tersebut pada umumnya senantiasa diawali dengan proses negosiasi antara para pihak. Melalui negosiasi para pihak berupaya menciptakan bentuk-bentuk kesepakatan untuk saling mempertemukan sesuatu yang diinginkan (kepentingan) melalui proses tawar-menawar. Pendek kata, pada umumnya kontrak bisnis justru berawal dari perbedaan kepentingan yang ingin dipertemukan melalui kontrak. Melalui kontrak perbedaan tersebut diakomodasi dan selanjutnya dibingkai dengan perangkat hukum sehingga mengikat para pihak. Dalam kontrak bisnis pertanyaan mengenai sisi kepastian dan keadilan justru akan tercapai apabila perbedaan yang ada di antara para pihak terakomodasi melalui

\footnotetext{
1 Yohanes Sogar Simamora, Prinsip Hukum Kontrak Dalam Pengadaan Barang Dan Jasa Oleh Pemerintah (Universitas Airlangga 2005).[25].

2 Bryan A Garner, Black's Law Dictionary Tenth Edition (tenth, west publishing company 2008).[389].
} 
mekanisme hubungan kontraktual yang bekerja secara proporsional". ${ }^{3}$ Maka dalam hal ini negosiasi merupakan hal yang sangat penting dan tidak dapat dipisahkan dalam menentukan isi kontrak itu sendiri.

Bahwa setelah ada kesepahaman atas kehendak untuk mengadakan kontrak antara para pihak, maka para pihak biasanya akan membuat Memorandum of Understanding yang memuat kesepakatan para pihak tentang hal-hal yang bersifat secara umum dan dibuat oleh para pihak sebelum kontrak itu dibuat secara rinci. ${ }^{4}$ Pembuatan MoU itu sendiri dilatarbelakangi oleh keinginan ataupun langkah untuk memastikan bahwa masing-masing pihak telah saling mengenal dan memiliki kesamaan pemahaman dalam upaya mengurangi resiko kegagalan dalam aktivitas bisnis mereka yang selanjutnya akan diikat dalam suatu kontrak. Selain itu MoU juga digunakan sebagai bagian dari negosiasi untuk menjajaki sampai sejauh mana mitra bisnis tersebut dapat memenuhi harapannya sebelum masuk tahap kepenandatanganan kontrak.

Di Indonesia, landasan hukum yang digunakan dalam praktik penggunaan MoU bertumpu pada prinsip kebebasan berkontrak, yang mana dasar hukumnya ialah dalam Pasal 1320 jo. Pasal 1338 ayat (1) BW, yang mana esensi dari MoU itu sendiri adalah kesepakatan secara umum untuk membuat perjanjian selanjutnya. Dalam hal ini dapat diketahui bahwa MoU bertujuan untuk melindungi pihak yang ingin membuat perjanjian yang mana dalam hal ini untuk mengetahui itikad baik dari pihak lawannya.

Terkait dengan esensi dari MoU yang mana merupakan perjanjian pendahuluan dan tidak mengikat para pihaknya, disini penerapan asas itikad baik merupakan hal yang sangat penting sebagai dasar tindak lanjut pembuatan kontrak selanjutnya. Disisi lain dalam MoU, apa yang telah disepakati oleh para pihak jika belum memuat hak dan kewajiban diantara para pihak, bukanlah

\footnotetext{
3 Agus Yudha Hernoko, Hukum Perjanjian Asas Proporsionalitas Dalam Kontrak Komersial (Kencana 2010).[1-2].

4 Salim H. S.[et.al], Perancangan Kontrak \& Memorandum of Understanding (MoU) (Sinar Grafika 2008).[86-87].
} 
perjanjian yang sesungguhnya, sehingga dalam hal ini akan menimbulkan resiko kerugian bila perjanjian ini tidak ditindak lanjuti. Dewasa ini, MoU hanyalah menjadi sebuah kerjasama berupa kesepahaman para pihak tanpa perkembangan signifikan. Bahkan saat ini banyak Mou yang tidak dilaksanakan lagi atau dilupakan karena sudah terlalu lama tidak ada aktivitas yang dijalankan. Adapun rumusan permasalahan yang akan menjadi pembahasan ialah pertama prinsipprinsip dalam pembentukan Memorandum of Understanding dan kedua ialah akibat hukum apabila salah satu pihak tidak beritikad baik dalam tindak lanjut Memorandum of Understanding.

Metode penelitian yang digunakan dalam penelitian ini adalah dengan menggunakan tipe penelitian Doctrinal Research, yaitu metode penelitian hukum yang pada dasarnya merupakan penelitian yang menghasilkan sebuah penjelasan yang sistematis mengenai aturan-aturan hukum yang mengatur sebuah kategori hukum tertentu, menganalisis hubungan antara aturan-aturan hukum, menjelaskan bidang-bidang yang sulit dan mungkin memprediksi perkembangan yang akan datang.

Pendekatan masalah yang digunakan, yaitu pendekatan konseptual (conceptual approach) dan pendekatan perundang-undangan (statute approach). Pendekatan konseptual dipilih karena dalam membahas isu hukum tersebut akan didasarkan pada konsep-konsep hukum yang relevan, dalam hal ini baik yang berupa konsep teknis yuridis yang terdapat dalam peraturan perundang-undangan, maupun konsep umum yang terdapat dalam literatur hukum lainnya. Dalam hal ini pendekatan konseptual digunakan untuk mengetahui teori-teori yang mendasari adanya MoU. Sedangkan pendekatan perundang-undangan dipilih karena dalam pembuatan kontrak haruslah berdasarkan peraturan perundang-undangan yang berlaku, yang mana dalam hal ini pendekatan perundang-undangan ini digunakan untuk mengetahui dasar pembentukan MoU di Indonesia serta akibat hukum dari pengingkaran $\mathrm{MoU}$ dengan tidak adanya itikad baik yang nantinya akan dikorelasikan dengan menggunakan pendekatan konseptual. 


\section{Prinsip-Prinsip dalam Pembentukan Memorandum of Understanding}

Perjanjian Pendahuluan atau Pactum de Contrahendo merupakan perjanjian yang digunakan sebagai pendahuluan untuk mengadakan perjanjian selanjutnya yang lebih rinci dan pasti. Pactum de Contrahendo dalam Black's Law Dictionary diartikan sebagai agreement to bargain. ${ }^{5}$ Bahwa dalam hal ini esensi dari perjanjian pendahuluan itu sendiri ialah kesepakatan untuk membuat perjanjian (agreed to agree). ${ }^{6}$

Van Dunne membagi kontrak kedalam 3 fase, yaitu fase prakontrak, fase kontrak dan fase pascakontrak (pre-contractual, contractual, post contractual). ${ }^{7}$ Fase prakontrak terjadi sebelum kontrak dirancang dan disusun yang berisi penawaran dan penerimaan, fase kontrak ialah adanya persesuaian pernyataan kehendak antara para pihak, sedangkan fase pascakontrak ialah saat pelaksanaan perjanjian itu sendiri. Dalam fase prakontrak, diantaranya ada 4 (empat) hal yang harus diperhatikan oleh para pihak, yaitu meliputi identifikasi para pihak, penelitian awal aspek terkait, pembuatan MoU dan Negosiasi. ${ }^{8}$ Setelah ada kesepahaman atas kehendak untuk mengadakan kontrak tersebut, maka para pihak biasanya akan membuat MoU yang memuat kesepakatan para pihak tentang hal-hal yang bersifat secara umum dan dibuat oleh para pihak sebelum kontrak itu dibuat secara rinci.

MoU dalam pengertian idealnya sebenarnya merupakan suatu bentuk perjanjian ataupun kesepakatan awal yang menyatakan langkah pencapaian saling pengertian antara kedua belah pihak (preliminary understanding of parties) untuk melangkah kemudian pada penandatanganan suatu kontrak. ${ }^{9}$ Black's Law Dictionary mendefinisikan MoU sama dengan Letter of Intent, yang mana pengertian Letter of Intent dalam Black's Law Dictionary ialah:

"A written statement detailing the preliminary understanding of parties who plan to enter into a contract or some other agreement; a noncommittal writing preliminary to a contract. A letter of intent is not meant to be binding and does

\footnotetext{
5 Garner (n 2)., ed., Op.Cit.[1283].

6 Yohanes Sogar Simamora, 'Perjanjian Pendahuluan Dalam Pengadaan Barang/Jasa Oleh Pemerintah' (2006) 21 Yuridika.[77].

7 Hernoko (n 3)., Op.Cit.[118].

8 Salim H. S.[et.al] (n 4)., Op.Cit.[86].

9 Ricardo Simanjuntak, Hukum Kontrak Teknik Perancangan Kontrak Bisnis (Kontan Publishing 2006).[8].
} 
not hinder the parties from bargaining with a third party. Businesspeople typically mean not to be bound by a letter of intent, and courts ordinarily do not enforce one; but courts occasionally find that a commitment has been made". ${ }^{10}$

Dari definisi diatas dapat diketahui bahwa MoU merupakan "sebuah pernyataan tertulis yang menjabarkan pemahaman awal pihak yang berencana untuk masuk ke dalam kontrak atau perjanjian lainnya, suatu tulisan tanpa komitmen/tidak menjanjikan suatu apapun sebagai awal untuk kesepakatan. Suatu Letter of Intent tidak dimaksudkan untuk mengikat dan tidak menghalangi pihak dari tawar-menawar dengan pihak ketiga. Pebisnis biasanya berarti tidak terikat dengan Letter of Intent, dan pengadilan biasanya tidak menerapkan salah satu, tapi pengadilan kadangkadang menemukan bahwa komitmen telah dibuat/disepakati." Sebagaimana diamati oleh Draetta, dalam penggunaan modern dari perjanjian pendahuluan, masing-masing pihak tampaknya disibukkan oleh kekhawatiran mengikat yang lain untuk tidak merundingkan kembali hal-hal dalam perjanjian yang telah dicatat, sementara pada saat yang sama menjaga untuk dirinya sendiri untuk mendapat kebebasan untuk merundingkan kembali. ${ }^{11}$

Berikut alasan dibuatnya MoU dalam suatu transaksi bisnis menurut Munir Fuady, yaitu: ${ }^{12}$

a. Karena prospek bisnisnya belum jelas benar, sehingga belum bisa dipastikan apakah deal kerja sama tersebut akan ditindaklanjuti atau tidak;

b. Karena dianggap penandatanganan kontrak masih lama dengan negosiasi yang alot. Karena itu, daripada tidak ada ikatan apa-apa sebelum ditandatanganinya kontrak tersebut, dibuatlah MoU yang akan berlaku untuk sementara waktu;

c. Karena masing-masing pihak dalam perjanjian masih ragu-ragu dan masih perlu waktu untuk pikir-pikir dalam hal menandatangani suatu kontrak, sehingga untuk pedoman awal dibuatlah MoU;

d. MoU dibuat dan ditandatangani oleh pihak eksekutif (direktur) dari suatu perusahaan tanpa memperhatikan hal detail terlebih dahulu dan tidak dirancang dan dinegoisasi khusus oleh staf-stafnya yang lebih rendah tetapi lebih menguasai teknis.

\footnotetext{
${ }^{10}$ Garner (n 2)., Op.Cit.[1044].

11 John Tarrant, 'Preliminary Agreement' (2006) 3 University of New England Law Journal. [155-156].

12 Munir Fuady, Hukum Bisnis Dalam Teori Dan Praktek (Citra Aditya Bakti 2002).[90].
} 
MoU sebagai suatu perjanjian pendahuluan dalam tahap prakontrak tunduk pada hukum kontrak, sehingga prinsip-prinsip dalam hukum kontrak juga haruslah diterapkan dalam MoU. Dalam hal ini prinsip-prinsip dasar dalam MoU ialah prinsip kebebasan berkontrak, prinsip konsensualisme, prinsip pacta sunt servanda, dan prinsip itikad baik, yang mana keempat ini merupakan prinsip yang sangat esensial bagi MoU.

Prinsip kebebasan berkontrak merupakan prinsip dasar dalam pembuatan MoU. MoU belum memiliki pengaturan secara khusus dan tidak dikenal dalam hukum konvensional di Indonesia, terutama dalam hukum kontrak di Indonesia. Di dalam peraturan perundang-undangan Indonesia, tidak ada ketentuan yang secara khusus mengatur mengenai MoU. Di Indonesia, landasan hukum yang digunakan dalam praktik penggunaan MoU bertumpu pada prinsip kebebasan berkontrak.

Buku III BW menganut sistem terbuka, yang mana dalam hal ini memberikan peluang bagi para pihaknya untuk mengatur sendiri pola hubungan hukum diantara mereka, yang mana buku III hanya mengatur dan melengkapi, dimana jika para pihak tidak mengatur beberapa hal didalam perjanjian mereka, maka dapat diguanakannya aturan dalam buku III BW. Hal ini berbeda dengan pengaturan dalam buku II BW yang menganut sistem tertutup dan bersifat memaksa, dimana para pihak dilarang menyimpangi aturan-aturan yang ada didalamnya. Dalam hal ini perlu diperhatikan bahwa prinsip kebebasan berkontrak bukan tanpa pembatasan. Di negara-negara penganut civil law, kebebasan berkontrak dibatasi oleh undang-undang, kepatutan, dan ketertiban umum (openbare orde). Menurut Hukum Indonesia, pembatasan terhadap prinsip kebebasan berkontrak tersebut dapat dikaitkan dengan salah satu syarat sah perjanjian sebagaimana dalam Pasal 1320 BW yang mana salah satunya ialah sebab yang tidak dilarang atau geoorloofde oorzaak..$^{13}$

Asas kebebasan berkontrak menurut pendapat Agus Yudha Hernoko, lahir sebagai manifestasi dari semangat liberalisme, dimana kebebasan individu dijunjung tinggi dan sangat diagung-agungkan. Pengaruh liberalisme ini juga mewarnai produk

${ }^{13}$ Peter Mahmud Marzuki, 'Batas-Batas Kebebasan Berkontrak' (2003) 18 Yuridika.[205-206]. 
hukum yang ada pada saat itu dan BW tidak terlepas dari pengaruh itu. Prinsip kebebasan berkontrak merupakan suatu prinsip yang memberikan keleluasaan atau kebebasan kepada para pihak untuk menyusun kontrak, baik yang sudah diatur maupun yang belum diatur oleh undang-undang. Prinsip ini dapat dianalisis dari ketentuan Pasal 1338 ayat (1) BW, yang berbunyi: "Semua perjanjian yang dibuat secara sah berlaku sebagai undang-undang bagi mereka yang membuatnya". Bahwa dari kata "semua perjanjian..." dapat ditafsirkan adanya prinsip kebebasan berkontrak. Dengan kata lain Pasal 1338 ayat (1) BW menyatakan dalam soal perjanjian, kita diperbolehkan membuat undang-undang bagi kita sendiri. Pasalpasal dalam Hukum Perjanjian hanya berlaku, apabila atau sekedar kita tidak mengadakan aturan-aturan sendiri dalam perjanjian yang kita buat.

Mengacu pada asas kebebasan berkontrak dan syarat-syarat sah suatu perjanjian, kebebasan para pihak tidak dapat dimaknai sebagai kehendak sepihak, akan tetapi kehendak dua belah pihak atau berbagai pihak. Kehendak para pihak di dalamnya tidak boleh ada unsur penipuan, kekhilafan, paksaan bahkan penyalahgunaan keadaan (misbruik van omstandigheiden) (das sollen). Dalam hal ini posisi kedua belah pihak haruslah seimbang, tidak boleh ada pihak yang lebih diuntungkan ataupun lebih dirugikan dalam pembentukan perjanjian tersebut.

Prinsip konsesualisme yaitu prinsip yang terkait dengan kesepakatan para pihak juga menjadi salah satu prinsip dasar pembuatan MoU. Konsensualisme berasal dari bahasa latin, yaitu consensus yang berarti sepakat. ${ }^{14}$ Konsensualisme dalam hal ini menghasilkan sebuah konsensus. Konsensus menurut Black's Law Dictionary merupakan "general agreement, collective opinion" yang mana dibentuk berdasarkan kesepakatan/ consent. ${ }^{15}$ Prinsip konsensualisme ini dapat disimpulkan dalam Pasal 1320 ayat (1) BW, bahwa pada pasal tersebut ditentukan salah satu syarat sahnya perjanjian adalah adanya kata kesepakatan diantara para pihak. Prinsip ini merupakan prinsip yang menyatakan bahwa perjanjian pada umumnya tidak diadakan secara formal, melainkan cukup dengan adanya kesepakatan kedua

\footnotetext{
14 J Satrio-I, Hukum Perjanjian (Citra Aditya Bakti 1992).[15].

15 Garner (n 2)., Op.Cit. [368].
} 
belah pihak. Kesepakatan adalah persesuaian antara kehendak dan pernyataan yang dibuat oleh kedua belah pihak. Maksud asas konsensualisme yang dianut sistem BW dalam hal ini ialah bahwa untuk melahirkan cukup dengan sepakat saja dan bahwa perjanjian itu (dan dengan demikian "perikatan” yang ditimbulkan karenanya) sudah dilahirkan pada saat itu atau detik tercapainya konsensus sebagaimana dimaksudkan diatas. Pada detik tersebut perjanjian sudah terjadi dan mengikat, bukan pada detik-detik lain yang terkemudian atau sebelumnya. ${ }^{16}$

Asas konsensualisme berkaitan dengan lahirnya kontrak. Lahirnya suatu kontrak diperlukan dengan adanya kesepakatan. Hal ini sesuai dengan asas konsensualisme yang terdapat dalam suatu perjanjian. Dengan kesepakatan dimaksudkan bahwa di antara pihak-pihak yang bersangkutan tercapai suatu persesuaian kehendak, artinya apa yang dikehendaki yang satu juga dikehendaki oleh yang lain. Jadi dalam hal ini, asas konsensualisme memiliki arti bahwa pada dasarnya perjanjian dan perikatan itu timbul karena sudah dilahirkan sejak detik tercapainya kesepakatan diantara para pihak. ${ }^{17}$

Prinsip inilah juga mendasari untuk pelaksanaan $\mathrm{MoU}$, karena $\mathrm{MoU}$ merupakan perjanjian pendahuluan yang para pihak sepakat untuk mengatur halhal pokok untuk melakukan transaksi bisnis. Pada pernyataan-pernyataan kehendak yang menghasilkan kesepakatan dibedakan antara penawaran dan penerimaan. Penawaran dapat dirumuskan sebagai pernyataan kehendak yang mengandung usul untuk mengadakan perjanjian. Hal ini mencakup esensialia perjanjian yang akan dibuat. Perjanjian timbul dengan adanya akseptasi. Sehingga dalam hal ini yang menentukan terjadinya kesepakatan adalah penerimaan. ${ }^{18}$

MoU lahir ketika para pihak bersepakat untuk melakukan transaksi bisnis yang didahului dengan negosiasi, dalam negosiasi inilah penawaran dan penerimaan terjadi yang kemudian lahirlah sebuah MoU sebagai nota kesepahaman

${ }^{16}$ Agus Yudha Hernoko, Azas Proporsionalitas Dalam Kontrak Komersial (Universitas Airlangga 2007).[12].

17 R. Subekti, Hukum Perjanjian (Intermasa 1992).[15].

${ }_{18}$ Niuwenhuis J H, Pokok-Pokok Hukum Perikatan (Terjemahan 1985).[2]. 
dan perjanjian pendahuluan. Dalam negosiasi para pihak telah menyepakati apa yang menjadi maksud para pihak dalam membuat perjanjian dan dituangkan dalam MoU. Jika sahnya sebuah perjanjian didasarkan pada prinsip ini, maka MoU adalah perjanjian mutlak sekalipun hanya perjanjian pendahuluan karena di dalamnya sudah jelas terjadi kesepakatan oleh karena itu MoU lahir. Maka tindak lanjut dari sebuah MoU menjadi perjanjian pokok adalah wajib.

Prinsip pacta sunt servanda atau prinsip daya mengikat juga merupakan prinsip yang harus diperhatikan dalam pembuatan MoU. Menurut Black's Law Dictionary, pacta sunt servanda merupakan bahasa latin dari "agreement must be kept", yang diartikan sebagai "the rule that agreements and stipulation, especially those contained in treaties, must be observed." Menurut J. Satrio, prinsip pacta sunt servanda/ prinsip janji itu mengikat adalah bahwa dalam perjanjian yang paling penting adalah isinya yakni keterikatan para pihak dalam perjanjian adalah keterikatan kepada isi perjanjian yang ditentukan oleh para pihak sendiri atau dianggap ditentukan oleh para pihak sendiri, maka orang sebenarnya terikat kepada janjinya sendiri, janji yang diberikan kepada pihak lain dalam perjanjian. Jadi orang terikat bukan karena ia menghendaki tetapi karena ia memberikan janjinya.

Prinsip pacta sunt servanda dikenal juga sebagai prinsip daya mengikat kontrak. Prinsip ini menjelaskan bahwa setiap perjanjian yang buat oleh para pihak dalam perjanjian itu, mengikat bagi para pihak itu sebagaimana undang-undang. Prinsip ini berkaitan dengan akibat dari perjanjian itu sendiri. Dalam hal ini prinsip pacta sunt servanda didasarkan dalam Pasal 1338 ayat (1) BW yang menyatakan bahwa "semua perjanjian yang dibuat secara sah berlaku sebagaimana undangundang bagi mereka yang membuatnya". Pengertian kalimat berlaku sebagai undang-undang bagi mereka yang membuatnya ini menunjukkan bahwa undangundang sendiri mengakui dan menempatkan posisi para pihak dalam kontak sejajar dengan pembuat undang-undang. Daya berlaku seperti undang-undang dalam kontrak dalam hal ini layaknya undang-undang yang buat oleh legislator dan karenanya harus ditaati oleh para pihak, bahkan jika dipandang perlu dapat dipaksakan dengan bantuan sarana penegakan hukum (hakim, juru sita). 
Pemberlakuan prinsip pacta sunt servanda merupakan prinsip yang amat mendasar dan vital bagi hukum kontrak. Prinsip ini juga memiliki karakter universal. Dalam MoU prinsip ini banyak disimpangi dengan alasan bukan merupakan perjanjian yang final. Padahal jika dilihat dari prinsip konsensualisme sebuah MoU adalah hasil kesepakatan awal, bagaimanapun juga merupakan kesepakatan yang harus dihormati dan dilaksanakan. Jika dikaitkan dengan prinsip ini maka pemberlakuannya sangat berkaitan dengan ada atau tidaknya kesepakatan antara para pihak.

Prinsip itikad baik termaksud prinsip paling mendasar dalam pelaksanaan MoU. Prinsip itikad baik mempunyai fungsi yang sangat penting tidak dalam pranata hukum kontrak. Prinsip ini ditempatkan sebagai asas yang paling penting (super eminent principle) dalam kontrak. ${ }^{19}$ Itikad baik merupakan sesuatu yang abstrak, sehingga menimbulkan banyak interpretasi atau penafsiran didalamnya. Dalam kaitan dengan penafsiran yang beragam ini tentunya akan mengarah ke subyektifitas masing-masing orang. Namun dalam konteks pembicaraan bidang hukum maka pengertian iktikad baik ini seringkali dihubungkan dengan kelayakan dan kepatutan. Kelayakan dan kepatutan mempunyai sifat yang obyektif, yaitu penekanan pada keadaan sekitar pembuatan hukum yang dilakukan. ${ }^{20}$

Prinsip itikad baik terdapat dalam Pasal 1338 ayat (3) BW yang menyatakan bahwa “...perjanjian harus dilaksanakan dengan itikad baik." Itikad baik bermakna bahwa kedua belah pihak harus berlaku satu dengan lainnya tanpa tipu daya, tanpa tipu muslihat, tanpa mengganggu pihak lain, tidak hanya melihat kepentingan diri sendiri saja, tetapi juga kepentingan pihak lainnya. Wirjono Prodjodikoro menyatakan bahwa dalam melaksanakan perbuatan ini kejujuran harus berjalan dalam hati sanubari seorang manusia. Jadi selalu mengingat bahwa manusia sebagai anggota masyarakat harus jauh dari sifat merugikan pihak lain, atau mempergunakan kata-kata secara membabi buta pada saat kedua belah pihak membuat perjanjian. Kedua belah pihak harus

19 A.F. Mason, 'Contract, Good Faith and Equitable Standard in Fair Dealing' (2000) 116 The Law Quarterly Review.[66].

${ }^{20}$ Hernoko (n 16).,Op.Cit.[16]. 
selalu memperhatikan hal-hal ini, dan tidak boleh mempergunakan kelalaian pihak lain untuk menguntungkan diri pribadi. ${ }^{21}$

Pasal 1338 ayat(3)BW juga menyatakan bahwa perjanjian harus dilaksanakan secara pantas dan patut, sebagaimana yang dikemukakan oleh Hofmann yaitu dalam Hukum Romawi terdapat perjanjian negotia banae fidei yang berarti hakim dapat memperluas atau memperkecil kewajiban-kewajiban para pihak dalam perjanjian yang bersangkutan, dalam hal demi kepatutan. Hal ini dimaksud bahwa, pasal tersebut mengandung asas bahwa, semua perjanjian yang memuat BW adalah perjanjian negotia bonae fidei. ${ }^{22}$

Dalam MoU prinsip ini sangat penting karena kewajiban beritikad baik dalam tahap negosiasi akan membawa tindak lanjut dari MoU yang menjadi perjanjian pendahuluan untuk dibawa menjadi perjanjian pokok. Tanpa adanya prinsip ini akan membawa pihak dalam MoU kedalam jurang yang mereka buat sendiri karena itikad baik ini memandang bahwa MoU merupakan tahap penting untuk ditindaklanjuti dan membuat MoU menjadi tidak lemah karena kewajiban ini memberikan kekuatan pada MoU untuk mengikat para pihaknya untuk menjalankan kewajiban atau prestasi yang dinyatakan dalam MoU.

J.M. van Dunne yang menyatakan bahwa daya berlaku itikad baik (goede trouw; good faith) meliputi seluruh proses kontrak atau diibaratkan dengan "the rise and fall of contract". Dengan demikian itikad baik meliputi 3 (tiga) fase perjalanan kontrak, yaitu: (i) pre contractuele fase, (ii) contractuele fase, dan (iii) postcontractuele fase. Prinsip itikad baik sangat penting bagi MoU dalam tahap prakontraktual terkait keberlanjutan MoU menjadi kontrak yang sebenarnya, selain itu dalam hal berjalannya kontrak para pihak juga harus melaksanakan isi kontrak dengan itikad baik, begitu pula dalam tahap pascakontraktual hukum acara perdata sendiri, prinsip itikad baik merupakan hal yang paling utama bagi hakim untuk menentukan keputusannya, baik dalam proses mediasi maupun proses dalam persidangan. ${ }^{23}$

\footnotetext{
${ }^{21}$ ibid. [16].

${ }^{22}$ Satrio-I (n 14)., Op.Cit.[177].

${ }^{23} \mathrm{Al}$. Ajrina Yuka Ardhira, [et., 'Itikad Baik Dalam Proses Mediasi Perkara Perdata Di Pengadilan (2018) 1 Media Iuris' (2018) 1 Media Iuris.[203].
} 
Pasal 1338 ayat (3) BW, pada umumnya selalu dihubungkan dengan Pasal 1339 BW, bahwa "Persetujuan tidak hanya mengikat apa yang dengan tegas ditentukan di dalamnya, melainkan juga segala sesuatu yang menurut sifatnya persetujuan dituntut berdasarkan keadilan, kebiasaan, atau undang-undang." Keadilan yang dimaksud di sini adalah itikad baik. ${ }^{24}$ Dengan demikian tindak lanjut MoU yang mana MoU itu sendiri merupakan bagian dari tahap prakontraktual sudah seharusnya dilandaskan asas itikad baik. Asas ini penting karena dengan adanya prinsip atau asas inilah rasa percaya sangat dibutuhkan dalam bisnis agar pembuatan kontrak dapat direalisasikan.

Prinsip ini menjadi titik tumpu pada MoU sebagai perjanjian pendahuluan agar menjadi pranaskah yang baik yang dapat menengahi dan mendasari kewajiban kontraktual, karena prinsip ini menuntut para pihak untuk saling memeriksa sebelum terjadi perjanjian pokok dan juga sebagai patokan untuk dilanjutkannya MoU, karena ketika MoU ini dibuat yang ada dalam pikiran para pihak adalah pembuatan perjanjian berdasarkan MoU dan pelaksanaan kontrak dengan baik. Sehingga tidak akan terjadi kerugian pada salah satu pihak jika MoU tidak dilanjutkan. Prinsip ini juga mampu membawa MoU sebagai perjanjian pendahuluan menjadi lebih kuat, namun tidak adanya ukuran pasti dari itikad baik ini juga memberikan kerancuan sejauh mana itikad baik dapat diberlakukan, karena bagaimanapun juga itikad baik merupakan niatan dari diri para pihak yang tidak dapat diukur oleh orang lain.

Keterkaitan antara ke empat prinsip dasar dalam pembuatan MoU ialah bahwa pembuatan MoU berlandaskan adanya prinsip kebebasan berkontrak karena dalam hal ini MoU merupakan salah satu bentuk perjanjian yang tidak diatur dalam BW. MoU berisi kesepakatan awal para pihak terkait hal-hal yang bersifat umum untuk mengadakan suatu perjanjian, MoU ini sendiri telah lahir karena kesepakatan para pihak tersebut, hal ini sesuai dengan prinsip konsensualisme yang mana terkait lahirnya suatu perjanjian. Kesepakatan awal tersebut walaupun belum bersifat final akan tetapi para pihak haruslah menghormati dan melaksanakan

${ }^{24}$ Hernoko (n 16)., Op.Cit.[136]. 
isi dari perjanjian tersebut, terutama jika dalam perjanjian tersebut memuat hak dan kewajiban para pihak, hal ini terkait dengan prinsip pacta sunt servanda. Berkaitan dengan pelaksanaan dari MoU, prinsip itikad baik lah yang memegang peran penting, karena prinsip ini yang memberi kekuatan pada MoU yang pada hakekatnya tidak mengikat para pihak. Melalui prinsip itikad baik ini para pihak dalam MoU sepatutnya melaksanakan MoU, yang mana MoU itu sendiri dibuat untuk selanjutnya diteruskan menjadi sebuah perjanjian yang sah dan mengikat para pihaknya.Bahwa terkait dengan substansi yang merupakan isi atau hal-hal lain yang diinginkan oleh kedua belah pihak yang dituangkan dalam MoU. Substansi MoU ada yang singkat, ada pula yang lengkap. Biasanya MoU dibuat secara sederhana dan tidak ada pengaturan yang lebih rinci, karena MoU hanya dianggap sebagai ikatan dasar dan kesepakatan awal yang mana hal detail terkait isi kontrak lebih jauh harus dinegosiasikan lagi dan dituangkan dalam kontrak yang sesungguhnya.

MoU yang pada dasarnya memiliki esensi dan fungsi sebagai perjanjian prakontrak, pada kenyataannya masih sering digunakan sebagai suatu tahapan yang berbeda. Hal inilah yang dapat menimbulkan kontroversi karena adanya inkonsistensi dalam pemakaiannya. Pada praktiknya, banyak MoU yang telah disepakati para pihak dapat langsung digunakan sebagai dasar menjalankan program-program kerja sama tanpa dibuatnya perjanjian sebenarnya yang lebih rinci, dalam kasus ini MoU bersifat mengikat para pihak karena MoU tersebut ialah sebagai dasar prestasi yang mereka berikan, sehingga telah terjadi hubungan timbal balik diantara para pihak dalam MoU tersebut.

Para pihak yang bermaksud mengadakan Nota Kesepahaman memiliki kewenangan untuk bersama-sama menentukan apa yang akan menjadi isi Nota Kesepahaman. Isi Nota Kesepahaman menggambarkan apa yang dikehendaki oleh mereka atau kedua belah pihak. Dalam praktik, perumusan isi Nota Kesepahaman ada yang singkat, ada pula yang lengkap, tergantung pada para pihak, mana yang mereka kehendaki. Dari kedua pola tersebut yang lebih banyak digunakan adalah rumusan secara singkat. Perumusan secara lebih terperinci atau panjang lebar diwujudkan dalam isi kontrak. Substansi MoU ini nantinya yang akan menjadi 
substansi kontrak yang dibuat secara lengkap dan detail oleh para pihak, sehingga MoU sebagai perjanjian pendahuluan seharusnya tidak memuat hak dan kewajiban diantara para pihak.

\section{Akibat Hukum Tidak Adanya Itikad Baik Oleh Salah Satu Pihak dalam Tindak Lanjut Memorandum of Understanding}

MoU merupakan perjanjian pendahuluan yang mana memiliki akibat hukum yang berbeda dengan perjanjian yang sesungguhnya. Dalam hal ini akibat hukum atas perjanjian yang sah ialah perjanjian tersebut berlaku sebagai undang-undang, tidak dapat ditarik kembali secara sepihak, dan harus dilaksanakan dengan itikad baik. ${ }^{25}$

MoU sebagai perjanjian pendahuluan yang mana dibuat berdasarkan adanya prinsip kebebasan berkontrak sebagaimana diatur dalam Pasal 1338 ayat (1) BW yang menyatakan bahwa "semua perjanjian yang sah berlaku sebagai undangundang bagi yang membuatnya.”, bila telah memenuhi syarat sahnya perjanjian maka menunjukkan bahwa MoU merupakan perjanjian yang sah dan mengikat para pihak. Dalam hal ini yang perlu diperhatikan ialah terkait dengan isi atau substansi dari MoU itu sendiri, sebagaimana yang telah dijelaskan, bahwa jika MoU sesuai dengan esensinya maka Pasal 1320 BW tersebut tidak akan terpenuhi karena dalam MoU belum secara detail diatur hak dan kewajiban bagi para pihak. Bahwa jika substansi yang termuat dalam MoU telah mencerminkan suatu kontrak maka MoU yang dimaksud tidak ada bedanya dengan perjanjian yang sesungguhnya dan dengan demikian berlakulah prinsip pacta sunt servanda. ${ }^{26}$ Dalam hal ini, dapat juga dimungkinkan MoU diatur kekuatan mengikatnya oleh para pihaknya, jika para pihak menentukan adanya kewajiban dilaksanakannya MoU tersebut maka demi hukum MoU tersebut memiliki kekuatan mengikat para pihaknya, hal ini juga terkait dengan adanya hak dan kewajiban para pihak yang dituangkan dalam MoU tersebut.

Munif Fuady berpendapat sebagaimana yang telah dijelaskan dalam bab sebelumnya, bahwa dalam suatu kegiatan bisnis, ada proses dimana proses itulah

\footnotetext{
${ }^{25}$ Abdulkadir Muhammad, Hukum Perdata Indonesia (Citra Aditya Bakti 2000).[233].

${ }^{26}$ ibid.[201-202].
} 
yang mengakibatkan bisnis tersebut bisa berjalan. Proses tersebut ialah dengan adanya pembuatan kontrak. Pembuatan kontrak tersebut terdapat tahapantahapannya, yaitu: ${ }^{27}$

1. Tahap prakontraktual, bahwa tahapan ini diawali dengan negosiasi, pembuatan MoU, studi kelayakan, negosiasi (lanjutan);

2. Tahap kontraktual, bahwa dalam tahap ini diawali dengan penulisan naskah awal, perbaikan naskah, penulisan naskah akhir, dan tahap ini akan diakhiri dengan penandatanganan kontrak;

3. Tahap pascakontraktual, ialah dimana dalam tahap ini didalamnya termasuk pelaksanaan, penafsiran dan penyelesaian sengketa.

Bahwa tahapan diatas hanyalah sebagai referensi yang diberikan oleh Munir Fuady, yang mana bukanlah hal mutlak yang harus dilakukan dalaam pembuatan kontrak. Bahwa atas dasar hal tersebut diatas, akibat hukum dari pembuatan MoU ialah dengan diadakannya pembuatan kontrak selanjutnya. Hal ini didasarkan dari karakteristik MoU itu sendiri yang hanyalah sebagai perjanjian pendahuluan yang mana hanya sebagai suatu pedoman awal tanda adanya suatu kesepahaman diantara para pihak. MoU sengaja dibuat dan sifatnya tidak formal karena biasanya hanya dilakukan di bawah tangan saja, dan sengaja dibuat ringkas karena pihak yang menandatangani MoU tersebut merupakan pihak-pihak masih dalam negosiasi awal, akan tetapi daripada tidak ada ikatan apa-apa maka dibuatlah MoU, sehingga dengan dibuatnya MoU maka dikemudian hari para pihak seharusnya melanjutkannya dengan pembuatan kontrak.

Bahwa dalam hal ini terhadap pelaksanaan MoU haruslah dilihat dari isi MoU itu terlebih dahulu. Pelaksanaan MoU agar memiliki kekuatan hukum haruslah ditindaklanjuti dengan membuat akta otentik yang di buat di hadapan notaris sebagai tindaklanjut dari MoU tersebut yang mana dalam hal ini ialah dengan dibuatnya perjanjian yang sebenarnya. Perjanjian yang sebenarnya dalam hal ini ialah perjanjian yang sempurna, yang mana memiliki kekuatan mengikat sebagaimana

${ }^{27}$ Fuady (n 12)., Op.Cit.[38]. 
diatur dalam Pasal 1338 ayat (1) BW yang menyatakan bahwa perjanjian yang dibuat secara sah berlaku sebagai undang-undang bagi para pihak yang membuatnya, yang mana berarti para pihak terikat untuk melaksanakan perjanjian yang mereka buat dan jika salah satu pihak mengingkari isi dari perjanjian yang telah mereka buat, maka pihak lainnya yang merasa dirugikan akibat pengingkaran tersebut dapat mengajukan gugatan atas kerugian yang dialaminya.

Tidak adanya pelaksanaan dalam hal ini perlu ditinjau terlebih dahulu alasan dari tidak adanya pelaksanaan tersebut. Dalam hal MoU sebagai perjanjian pendahuluan, jika alasan tidak adanya pelaksanaan ialah karena para pihak tidak menghendaki adanya pembuatan kontrak yang sebenarnya, maka hal tersebut berarti tidak diteruskannya MoU menjadi sebuah perjanjian. Tidak diteruskannya MoU menjadi sebuah perjanjian mengakibatkan MoU tersebut menjadi batal. Hal ini sebagaimana dinyatakan Munif Fuady yang menyatakan dalam ciri-ciri MoU, yang salah satunya ialah memiliki jangka waktu. Bahwa apabila dalam jangka waktu tersebut MoU tidak ditindaklanjuti dengan penandatanganan suatu perjanjian yang lebih rinci, maka MoU tersebut akan batal, kecuali diperpanjang oleh para pihak. ${ }^{28}$ Ahmadi Miru berpendapat terhadap perjanjian yang mana dengan sendirinya batal, mengakibatkan hapusnya perjanjian tersebut. ${ }^{29}$ Agus Yudha Hernoko berpendapat mengenai perlu dibedakannya pemahaman antara hapusnya kontrak karena pembatalan dengan hapusnya perikatan sebagaimana dimaksud dalam Pasal 1381 BW diatas. Bahwa hapusnya kontrak karena pembatalan jelas menghapus eksistensi kontrak, sedangkan hapusnya perikatan karena pembayaran atau pemenuhan prestasi hanya menghapus perikatannya sendiri namun eksistensi kontraknya tidak hapus. ${ }^{30}$

MoU yang sifatnya bukan merupakan suatu kontrak dimana tidak terdapat hak dan kewajiban para pihak didalamnya dan tidak ditindak lanjuti dengan membuat akta

\footnotetext{
28 ibid., Op.Cit.[92].

29 Ahmadi Miru, Hukum Kontrak Dan Perancangan Kontrak (Rajagrafindo Persada 2008).

${ }^{30}$ Hernoko (n 3)., Op.Cit.[294].
} [109]. 
otentik yang diperbuat di hadapan notaris tidak memiliki kekuatan yang mengikat, maka tidak ada sanksi apapun bagi pihak yang mengingkarinya kecuali sanksi moral. Dalam hal MoU sebagai perjanjian yang sesungguhnya, yang mana memuat hak dan kewajiban para pihak didalamnya, tidak ada pelaksanaan dari MoU berarti sama dengan tidak adanya pelaksanaan dari perjanjian, jika tidak adanya pelaksanaan dikarenakan adanya kesepakatan para pihak maka dapat dilakukan pembatalan atau pemutusan perjanjian. Dalam hal tidak adanya pelaksanaan perjanjian yang disebabkan oleh salah satu pihak, hal tersebut dapat menimbulkan tanggung gugat kepada pihak yang tidak melaksanakan perjanjian tersebut.

MoU dibuat untuk ditindaklanjuti, memberikan para pihak waktu untuk berpikir ulang apakah akan mengikatkan diri, serta mempersiapkan hal-hal yang dituangkan atau dibutuhkan dalam perjanjian kerjasama. Sehingga landasan utama pembuatan maupun pelaksanaan MoU merupakan itikad baik para pihak. Dalam tahap prakontrak ini masing-masing pihak harus menegakkan prinsip itikad baik, yang oleh karena itu jika salah satu pihak beritikad buruk, maka haruslah disediakan sarana hukum berupa hak gugat dan hak untuk menuntut ganti rugi dalam tahap prakontrak.

Pengakhiran MoU oleh salah satu pihak dengan itikad tidak baik dapat mengakibatkan kerugian oleh pihak lainnya. Berbagai pendapat dikemukakan oleh para ahli tentang kerugian, menurut Nieuwenhuis kerugian adalah berkurangnya harta kekayaan pihak yang satu, yang disebabkan oleh perbuatan (melakukan atau membiarkan) yang melanggar norma oleh pihak yang lain. Kerugian merupakan selisih yang merugikan antara keadaan yang timbul sebagai akibat pelanggaran norma (dapat berupa perbuatan melanggar hukum maupun wanprestasi) dan situasi yang seyogyanya akan timbul andaikata pelanggaran norma tersebut tidak terjadi. ${ }^{31}$ Lebih jauh Yohanes Sogar Simamora menjelaskan:32 "Bahwa pengingkaran terhadap MoU yang berkekuatan selayaknya kontrak pada umunya, melahirkan hak bagi pihak lain untuk mengajukan gugatan wanprestasi. Sebaliknya, jika MoU yang

31 Ghansham Anand, Karakteristik Jabatan Notaris Di Indonesia Dan Batas Tanggung Gugatnya (Fakultas Hukum Universitas Airlangga 2013).[44-45].

32 Yohanes Sogar Simamora (n 6).,Op.Cit.[78]. 
dimaksud memang bermakna sebagai perjanjian pendahuluan, gugatan wanprestasi tentu akan ditolak hakim. Dalam situasi ini, dari perspektif hukum positif Indonesia, bagi pihak yang yang dirugikan tidak ada pilihan lain kecuali menggunakan dasar gugatan perbuatan melanggar hukum sebagaimana diatur dalam Pasal 1365 BW."

Subekti menyatakan seseorang dikatakan melakukan wanprestasi ketika ia yang berjanji, tetapi tidak melakukan apa yang dijanjikannya, ia alpa, lalai atau ingkar janji atau juga ia melanggar perjanjian, bila ia melakukan atau berbuat sesuatu yang tidak boleh dilakukannya. ${ }^{33}$ Menurut Abdulkadir Muhammad, wanprestasi merupakan tidak memenuhi sesuatu yang diwajibkan seperti yang telah ditetapkan dalam perikatan. ${ }^{34}$

MoU sebagai perjanjian pendahuluan hanya memuat hal yang bersifat umum, dimana didalamnya tidaklah terkadung hak dan kewajiban para pihak. Sehingga dalam hal ini MoU tidaklah bersifat mengikat dan tidak dapat dipaksakan pelaksanaannya. Akan tetapi dalam hal ini jika MoU tersebut telah menyatakan mengenai kewajiban para pihaknya, maka MoU tersebut memiliki kekuatan hukum dan mengikat para pihaknya, sehingga dapat dipaksakan pelaksanaannya.

Bahwa jika substansi dalam MoU telah berisi sebagaimana mencerminkan perjanjian yang sesungguhnya, maka MoU tersebut tidak ada bedanya dengan perjanjian sebagaimana diatur dalam pasal 1313 BW. Sehingga pengingkaran terhadap MoU yang berkekuatan mengikat selayaknya perjanjian yang sesungguhnya, yang mana dalam hal ini ialah dengan melakukan pengakhiran MoU oleh pihak dengan tidak adanya itikad baik, dapat diajukan gugatan ganti rugi atas dasar wanprestasi. Agus Yudha Hernoko berpendapat bahwa dengan adanya wanprestasi, pihak yang dirugikan sebagai akibat kegagalan pelaksanaan perjanjian oleh pihak lainnya, mempunyai hak gugat dalam upaya menegakkan hak-hak kontraktualnya. ${ }^{35}$ Dalam hal ini gugatan yang dapat diajukan kepada pihak yang melakukan pengakhiran MoU dengan tidak adanya itikad baik atas

\footnotetext{
${ }^{33}$ R. Subekti (n 17)., Op.Cit.[45].

${ }^{34}$ Abdulkadir Muhammad (n 25)., Op.Cit.[203].

${ }_{35}$ Hernoko (n 3)., Op.Cit.[262-263].
} 
dasar wanprestasi ialah pemenuhan perjanjian, ganti rugi (pengganti), pembubaran, pemutusan, pembatalan, dan pemenuhan atau pembubaran ditambah ganti rugi.

Terhadap MoU yang substansinya konsisten dengan esensi dari MoU sebagai perjanjian pendahuluan yang mana didalamnya tidak memuat hak dan kewajiban para pihak, akan tidak tepat jika mengajukan gugatan wanprestasi, yang mana tentunya gugatan tersebut akan ditolak oleh hakim, karena gugatan wanprestasi hanya terkait pengingkaran dari isi perjanjian, sedangkan MoU tidak memuat hak dan kewajiban para pihak sehingga jika esensi MoU sebagaimana perjanjian pendahuluan maka seyogyanya tidak ada pengingkaran dari MoU itu sendiri. Bagi pihak yang dirugikan dari tidak dilanjutkannya MoU akan lebih tepat untuk mengajukan gugatan melanggar hukum. Dalam hal melakukan suatu gugatan atas dasar perbuatan melanggar hukum, penggugat harus membuktikan semua unsurunsur perbuatan melanggar hukum selain harus mampu membuktikan adanya kesalahan yang diperbuat tergugat. Pencantuman syarat kesalahan pada Pasal 1365 BW bertujuan bahwa pelaku perbuatan melanggar hukum, hanya bertanggung jawab atas kerugian yang ditimbulkannya apabila perbuatan itu dapat dipersalahkan kepadanya. Suatu perbuatan dianggap oleh hukum mengandung syarat kesalahan sehingga dapat dimintakan pertanggung jawaban secara hukum apabila memenuhi unsur-unsur berikut: terdapat unsur kesengajaan, terdapat unsur kelalaian dan tidak ada alasan pembenar atau alasan pemaaf seperti keadaan overmatch, membeli diri, tidak waras, dan sebagainya. ${ }^{36}$

MoU sebagai perjanjian pendahuluan yang tidak memuat hak dan kewajiban diantara pihaknya tidak memiliki kekuatan mengikat, sehingga jika terjadi pengakhiran perjanjian dengan tidak adanya itikad baik hanya dimungkinkan untuk mengajukan gugatan dengan dasar perbuatan melanggar hukum, bukan wanprestasi, hal ini dikarenakan tidak ada hubungan kontraktual diantara para pihak. Dalam hal ini sebagaimana telah diketahui bahwa perbuatan melanggar hukum dapat terjadi bila salah satu pihak merugikan pihak lain dengan suatu kesengajaan ataupun

${ }^{36}$ Conan Budi Wijaya, 'Kedudukan Hukum Pembeli Satuan Rumah Susun Yang Berbentuk Perjanjian Pengikatan Jual Beli (Studi Kasus Apartemen Puncak Permai)’ (2018) 1 Notaire.[240]. 
ketidaksengajaaan dan menimbulkan kerugian pada salah satu pihak, hal ini termaksud dengan adanya itikad tidak baik. Adanya itikad tidak baik dapat menjadi dasar pengajuan gugatan perbuatan melawan hukum.

Bahwa dalam hal ini gugatan yang dapat diajukan kepada pihak yang melakukan pengakhiran MoU dengan tidak adanya itikad baik atas dasar perbuatan melanggar hukum ialah gugatan ganti rugi, pernyataan hukum dan perintah atau larangan hakim. Gugatan ganti rugi dalam hal ini berdasarkan Pasal 1365 BW yang mengharuskan setiap perbuatan melanggar hukum yang membawa kerugian kepada pihak lain, maka orang tersebut karena salahnya, mengganti kerugian atas perbuatan tersebut. Dalam hal ini gugatan ganti kerugian atas perbuatan melanggar hukum jauh lebih memungkinkan dibandingan atas wanprestasi hal ini mengingat karena memang belum terjadi kontrak antar para pihak, maka tidaklah mungkin apabila terjadi wanprestasi antar para pihak. Sedangkan gugatan perbuatan melanggar hukum sangat dimungkinkan mengingat unsurunsur Pasal 1365 BW telah terpenuhi.

\section{Kesimpulan}

Hukum positif di Indonesia belum mengatur dengan jelas mengenai MoU. Eksistensi MoU didasarkan karena adanya prinsip kebebasan berkontrak. MoU merupakan perjanjian pendahuluan yang digunakan sebagai pendahuluan untuk mengadakan perjanjian selanjutnya yang lebih rinci dan pasti, yang termasuk kedalam fase prakontrak dan tidak memiliki kekuatan mengikat. Dalam hal ini walaupun termasuk dalam fase prakontrak, para pihak diwajibkan untuk menerapkan prinsip itikad baik dalam pembuatan dan pelaksanaan MoU, karena prinsip itikad baik ini memandang bahwa MoU merupakan tahap penting untuk ditindaklanjuti dan juga prinsip ini menjadikan MoU tidak lemah karena kewajiban ini memberikan kekuatan pada MoU untuk mengikat para pihaknya untuk menjalankan kewajiban atau prestasi yang dinyatakan dalam MoU. Sehingga dalam hal ini prinsip-prinsip dalam pembuatan MoU ialah prinsip kebebasan berkontrak, prinsip konsensualisme, prinsip daya mengikat kontrak (pacta sunt servanda) dan prinsip itikad baik. 
Substansi dari MoU ialah berisi kesepakatan para pihak tentang hal-hal yang bersifat umum, dan bukannya berisi hak dan kewajiban para pihak. Jika substansi MoU memuat hak dan kewajiban para pihak, maka MoU tersebut telah kehilangan esensinya sebagai perjanjian pendahuluan dan mengakibatkan $\mathrm{MoU}$ tersebut mengikat para pihaknya dan memiliki kekuatan hukum, sehingga segala bentuk pelanggaran dari MoU dapat diajukan gugatan atas perbuatan wanprestasi ataupun perbuatan melanggar hukum. Bahwa terhadap MoU sebagai perjanjian pendahuluan tidak dapat diajukan gugatan wanprestasi karena dalam MoU tersebut tidak memuat hak dan kewajiban sehingga tidak ada janji yang diingkari, akan tetapi dapat diajukan gugatan perbuatan melanggar hukum atas kerugian yang diderita oleh pihak yang dirugikan akibat pengingkaran dari MoU tersebut.

\section{Daftar Bacaan}

\section{Buku}

Abdulkadir Muhammad, Hukum Perdata Indonesia (Citra Aditya Bakti 2000).

Fuady M, Hukum Bisnis Dalam Teori Dan Praktek (Citra Aditya Bakti 2002).

Garner BA, Black's Law Dictionary Tenth Edition (tenth, west publishing company 2008).

H NJ, Pokok-Pokok Hukum Perikatan (Terjemahan, 1985).

—, Hukum Perjanjian Asas Proporsionalitas Dalam Kontrak Komersial (Kencana 2010).

Miru A, Hukum Kontrak Dan Perancangan Kontrak (Rajagrafindo Persada 2008). R. Subekti, Hukum Perjanjian (Intermasa 1992).

Salim H. S.[et.al], Perancangan Kontrak \& Memorandum of Understanding (MoU) (Sinar Grafika 2008).

Satrio-I J, Hukum Perjanjian (Citra Aditya Bakti 1992).

Simanjuntak R, Hukum Kontrak Teknik Perancangan Kontrak Bisnis (Kontan Publishing 2006). 


\section{Jurnal}

A.F. Mason, 'Contract, Good Faith and Equitable Standard in Fair Dealing' (2000) 116 The Law Quarterly Review.

Ajrina Yuka Ardhira, [et. A., 'Itikad Baik Dalam Proses Mediasi Perkara Perdata Di Pengadilan (2018) 1 Media Iuris' (2018) 1 Media Iuris.

Peter Mahmud Marzuki, ‘Batas-Batas Kebebasan Berkontrak’ (2003) 18 Yuridika.

Tarrant J, 'Preliminary Agreement' (2006) 3 University of New England Law Journal.

Wijaya CB, 'Kedudukan Hukum Pembeli Satuan Rumah Susun Yang Berbentuk Perjanjian Pengikatan Jual Beli (Studi Kasus Apartemen Puncak Permai)' (2018) 1 Notaire.

Yohanes Sogar Simamora, 'Perjanjian Pendahuluan Dalam Pengadaan Barang/Jasa Oleh Pemerintah’ (2006) 21 Yuridika.

\section{Thesis}

Anand G, 'Karakteristik Jabatan Notaris Di Indonesia Dan Batas Tanggung Gugatnya' (Fakultas Hukum Universitas Airlangga 2013).

Hernoko AY, 'Azas Proporsionalitas Dalam Kontrak Komersial' (Universitas Airlangga 2007).

Simamora YS, 'Prinsip Hukum Kontrak Dalam Pengadaan Barang Dan Jasa Oleh Pemerintah' (Universitas Airlangga 2005 2005).

HOW TO CITE: Margaretha Donda Daniella, William Tandya Putra and Erich Widjaja Kurniawan, 'Asas Itikad Baik dalam Memorandum of Understanding Sebagai Dasar Pembuatan Kontrak' (2019) Vol. 2 No. 2 Notaire. 
--Halaman ini sengaja dibiarkan kosong-- 